\title{
Airway function in infants with vascular rings: preoperative and postoperative assessment
}

\author{
A H Thomson, C S Beardsmore, R Firmin, R Leanage, H Simpson
}

\begin{abstract}
Aortic arch anomalies in infancy often cause intrathoracic airway obstruction. Airway function was assessed as part of the diagnostic evaluation in six symptomatic infants both by plethysmography and using a chest compression technique to obtain partial flowvolume loops. Two infants had normal intrathoracic airway function and their symptoms were unrelated to aortic arch abnormalities. The remaining four had complete vascular rings (three double aortic arch, one pulmonary sling) and had increased expiratory airway resistance (Raw) (mean Raw $=700 \%$ predicted) and greatly decreased maximum flow rates at functional residual capacity ('ंmaxFRC; mean V́maxFRC $=34 \%$ predicted) with gross shape abnormalities of the flowvolume loop. Postoperatively airway function was substantially improved (mean $R a w=175 \%$ predicted, $\dot{\text { maxFRC }}=79 \%$ predicted) but some abnormality of flow-volume loop shape remained, suggesting that tracheal dynamics were not completely normal in the early postoperative period.
\end{abstract}

Anomalies of the aortic arch complex account for less than $1 \%$ of congenital cardiac malformations but frequently cause airway obstruction presenting in infancy. Surgical division of a vascular ring, first reported in $1945,{ }^{1}$ is now considered safe and effective in providing symptomatic relief. Two recent reports on the long term follow up of airway function after surgery for vascular ring, however, have shown residual lung function abnormalities in $55-80 \%$ of cases despite symptomatic improvement. ${ }^{2} 3$ Objective assessment of airway function before and after operation, which demonstrates the immediate effectiveness of surgical intervention, has not been reported previously.

Patients and methods

Over an 18 month period all six infants presenting to a regional centre with symptoms of airway obstruction in association with aortic arch anomalies had full lung function assessment as part of their diagnostic evaluation. Four of these infants required surgical treatment and repeat measurements were made at a mean of eight weeks postoperatively (six to 10 weeks). All were clinically stable and breathing room air at the time of the studies. Table 1 gives clinical details of the infants. The investigative approach to these infants with stridor was to examine the airway radiologically using a
Cincinnati filter and perform a barium swallow to look for indentation of the oesophagus in all cases. Laryngoscopy and bronchoscopy were performed selectively. All infants had cardiac catherisation.

ASSESSMENT OF LUNG FUNCTION

The infants were sedated with chloral hydrate $(60-100 \mathrm{mg} / \mathrm{kg})$ and measurements made of thoracic gas volume (TGV) and airway resistance (Raw) in a modified Jaeger whole body plethysmograph. ${ }^{4}$ Predicted values for TGV and Raw were calculated from the equations: $\mathrm{TGV}(\mathrm{ml})=-239+6 \cdot 77 \times$ length $(\mathrm{cm})$ and Raw $=1 /$ Gaw (airway conductance); Gaw $=$ $-0.47+0.016 \times$ length $(\mathrm{cm})$ respectively (J Stocks, C Dezateax, personal communication). Inspiratory resistance was calculated at $50 \%$ initial inspiratory flow and expiratory resistance was calculated at $50 \%$ end expiratory flow and expressed as a percentage of the predicted inspiratory values (predicted expiratory values unavailable). Partial expiratory flow-volume curves were obtained using a chest compression technique. ${ }^{5}$ Briefly, the infant was placed in a double thickness polythene jacket extending from shoulders to thighs and breathed through a facemask attached to a heated screen pneumotachograph. Tidal flow-volume loops were recorded and at the end of a normal inspiration the jacket was rapidly inflated causing chest compression and rapid expiratory flow. Forced partial expiratory flow-volume curves were thus obtained. The maximum flow rate at functional residual capacity ( $\dot{\mathrm{V} m a x F R C)}$ ) and the ratio of forced maximum expiratory flow to tidal flow at midtidal volume (Vmid forced/tidal) were calculated. The single best value from the technically acceptable data is given for VmaxFRC: predicted values were taken from Shulman et al. ${ }^{6}$

Results

GENERAL INVESTIGATION

The ring formed by a double aortic arch resulted in classical symptoms, signs, and appearances on radiography in cases 1,2 , and 3 (tables 1 and 2). The symptoms from a pulmonary sling in case 4 were more variable and the infant presented later in respiratory distress and with two episodes of 'collapse' before referral. A soft tissue shadow between the trachea and oesophagus was missed on the first barium swallow but found on a subsequent test after intrathoracic narrowing of the trachea had been shown on a Cincinnati airway view. The finding
Department of Paediatrics, Headington

Oxford OX3 9DU.

Accepted 12 September 1989 
Table 1 Clinical details

\begin{tabular}{|c|c|c|c|c|c|c|c|c|}
\hline \multirow{3}{*}{$\begin{array}{l}\text { Case } \\
\text { No }\end{array}$} & \multicolumn{4}{|l|}{ Symptoms } & \multicolumn{4}{|l|}{ Signs } \\
\hline & \multirow{2}{*}{$\begin{array}{l}\text { Age at } \\
\text { presentation } \\
\text { (weeks) }\end{array}$} & \multirow{2}{*}{$\begin{array}{l}\text { Noisy } \\
\text { breathing }\end{array}$} & \multirow{2}{*}{$\begin{array}{l}\text { Feeding } \\
\text { difficulties }\end{array}$} & \multirow[t]{2}{*}{ Apnoea } & \multicolumn{2}{|l|}{ Stridor } & \multirow[t]{2}{*}{ Indrawing } & \multirow[t]{2}{*}{ Wheeze/rhonch } \\
\hline & & & & & Inspiratory & Expiratory & & \\
\hline 1 & 5 & + & + & - & + & + & + & + \\
\hline 2 & 2 & + & - & - & + & + & + & - \\
\hline 3 & 30 & + & - & - & + & + & + & - \\
\hline 4 & 20 & + & - & + & + & + & + & + \\
\hline 5 & 14 & + & + & - & + & - & + & - \\
\hline 6 & 7 & + & - & + & + & - & - & - \\
\hline
\end{tabular}

Table 2 Results of investigations

\begin{tabular}{|c|c|c|c|c|}
\hline $\begin{array}{l}\text { Case } \\
\text { No }\end{array}$ & Bronchoscopy & Barium swallow & Cincinnati views & Anatomical diagnosis \\
\hline 1 & - & $\begin{array}{l}\text { Posterior and left lateral } \\
\text { compression of oesophagus }\end{array}$ & Trachea deviated to right & $\begin{array}{l}\text { Complete double aortic arch } \\
\text { of equal dimensions }\end{array}$ \\
\hline 2 & $\begin{array}{l}\text { Trachea narrow above } \\
\text { carina }\end{array}$ & $\begin{array}{l}\text { Posterior compression of } \\
\text { oesophagus }\end{array}$ & $\begin{array}{l}\text { Anteroposterior compression } \\
\text { of trachea }\end{array}$ & $\begin{array}{l}\text { Incomplete double aortic arch } \\
\text { with ligament on left }\end{array}$ \\
\hline 3 & - & $\begin{array}{l}\text { Posterior and left lateral } \\
\text { compression of oesophagus }\end{array}$ & $\begin{array}{l}\text { Narrowing trachea above } \\
\text { carina }\end{array}$ & Complete double aortic arch \\
\hline 4 & - & $\begin{array}{l}\text { (1) Normal } \\
\text { (2) Soft tissue shadow } \\
\text { between lower } \\
\text { oesophagus and trachea }\end{array}$ & $\begin{array}{l}\text { Narrowing intrathoracic } \\
\text { trachea }\end{array}$ & $\begin{array}{l}\text { Anomalous left pulmonary } \\
\text { artery-pulmonary sling }\end{array}$ \\
\hline 5 & $\begin{array}{l}\text { Laryngomalacia, posterior } \\
\text { indentation of trachea }\end{array}$ & $\begin{array}{l}\text { Posterior compression of } \\
\text { oesophagus }\end{array}$ & Normal & $\begin{array}{l}\text { Left arch with anomalous } \\
\text { right subclavian }\end{array}$ \\
\hline 6 & - & $\begin{array}{l}\text { Posterior compression of } \\
\text { oesophagus }\end{array}$ & Normal & $\begin{array}{l}\text { Left arch with anomalous } \\
\text { right subclavian }\end{array}$ \\
\hline
\end{tabular}

of expiratory stridor on examination distinguished these four infants with aortic arch anomalies resulting in intrathoracic airways compression.

Case 5 had laryngomalacia but also indentation of the oesophagus on a barium swallow and a probable posterior indentation of the trachea at bronchoscopy, and in case 6 the severity of the symptoms and oesophageal indentation led to further investigation. Both infants were found to have left aortic arch with anomalous right subclavian vessels.

\section{LUNG FUNCTION ASSESSMENT}

Severe air flow limitation due to upper respiratory obstruction was demonstrated in five of the infants (table 3 ). Intrathoracic obstruction was the main problem in cases 1-3. The degree of airway obstruction was such that the thoracic gas volume could not be measured accurately in case 1 , while in all three infants Raw was appreciably raised during expiration (fig 1) even during tidal breathing. All demonstrated a profound decrease in forced expiratory flow rates as shown in fig 2a. Surgery resulted in dramatic improvement in airway function during both tidal and forced expiration (table 2, fig 2b) but all had some residual abnormality of flowvolume shape.

In case 4 no abnormalities were detectable during tidal breathing but a substantial decrease in VmaxFRC and extreme variability in maximum expiratory flow during each breath suggested a dynamic component to the airway narrowing, which was not observed in the other infants studied. There was a great improvement postoperatively, particularly in the forced expiratory flow rates, although the flow patterns were still variable.

Case 5 showed extrathoracic airway obstruction on lung function testing, with greatly

Table 3 Lung function results

\begin{tabular}{|c|c|c|c|c|c|c|c|c|c|c|}
\hline \multirow[t]{3}{*}{ Case No } & \multirow{3}{*}{$\begin{array}{l}\text { Length } \\
(\mathrm{cm})\end{array}$} & \multirow{3}{*}{$\begin{array}{l}\text { Thoracic gas } \\
\text { volume } \\
\text { (\% predicted })\end{array}$} & \multicolumn{2}{|c|}{ Raw $(x \% \text { predicted })^{*}$} & \multirow{3}{*}{$\begin{array}{l}\dot{V} \max F R C \\
(\% \text { predicted })\end{array}$} & \multirow{2}{*}{$\begin{array}{l}\text { Midtidal } \\
\text { expiratory: } \\
\text { inspiratory } \\
\text { ratio }\end{array}$} & \multirow{3}{*}{$\begin{array}{l}\begin{array}{l}\text { Vmid } \\
\text { forced/tidal } \\
\text { ratio }\end{array} \\
\text { Mean }(S D)\end{array}$} & \multirow{3}{*}{$\begin{array}{l}\text { Functional } \\
\text { diagnosis }\end{array}$} & \multirow{3}{*}{$\begin{array}{l}\text { Time } \\
\text { after } \\
\text { operation } \\
\text { (weeks) }\end{array}$} & \multirow{3}{*}{$\begin{array}{l}\text { Symptomatic } \\
\text { improvement }\end{array}$} \\
\hline & & & \multirow[t]{2}{*}{ Inspiratory } & \multirow[t]{2}{*}{ Expiratory } & & & & & & \\
\hline & & & & & & No Mean $(S D)$ & & & & \\
\hline 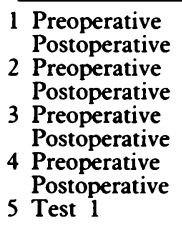 & $\begin{array}{l}56 \cdot 4 \\
61 \cdot 8 \\
55 \\
62 \\
70 \cdot 8 \\
71 \cdot 8 \\
66 \cdot 9 \\
69 \cdot 5 \\
58 \cdot 5\end{array}$ & $\begin{array}{r}- \\
88 \\
155 \\
92 \\
86 \\
81 \\
73 \\
89 \\
104\end{array}$ & $\begin{array}{l}5 \dagger \\
2 \\
6 \\
0 \cdot 5 \\
6 \\
1 \cdot 5 \\
3 \\
2 \\
21\end{array}$ & $\begin{array}{c}40 \dagger \\
2 \\
15 \\
1 \\
10 \\
2 \\
1 \\
2 \\
3\end{array}$ & $\begin{array}{l}27 \\
76 \\
19 \\
90 \\
38 \\
53 \\
51 \\
97 \\
96\end{array}$ & $\begin{array}{ll}4 & 0 \cdot 27(0.06) \\
4 & 0.63(0.14) \\
4 & 0 \cdot 36(0.05) \\
5 & 0 \cdot 57(0.04) \\
4 & 0 \cdot 49(0.05) \\
4 & 0 \cdot 55(0.07) \\
5 & 0 \cdot 72(0.05) \\
4 & 0.59(0.06) \\
6 & 0.61(0.06)\end{array}$ & $\begin{array}{l}1.00(0.01) \\
3.74(0.51) \\
1.00(0.01) \\
3.46(0.41) \\
1.89(0.12) \\
4.98(0.42) \\
1.91(0.12) \\
3.57(0.38) \\
5.34(0.68)\end{array}$ & $\begin{array}{l}\text { Intrathoracic } \\
\text { airways obstruction } \\
\text { Intrathoracic } \\
\text { airways obstruction } \\
\text { Intrathoracic } \\
\text { airways obstruction } \\
\text { Intrathoracic } \\
\text { airways obstruction } \\
\text { Extrathoracic }\end{array}$ & $\begin{array}{r}6 \\
10\end{array}$ & $\begin{array}{l}\text { Yes } \\
\text { Yes }\end{array}$ \\
\hline 6 Test 1 & $57 \cdot 4$ & 88 & 0.5 & 0.5 & 140 & $40.81(0.01)$ & $4 \cdot 10(0.61)$ & $\begin{array}{l}\text { Intermittent } \\
\text { extrathoracic } \\
\text { airways obstruction }\end{array}$ & & - \\
\hline
\end{tabular}




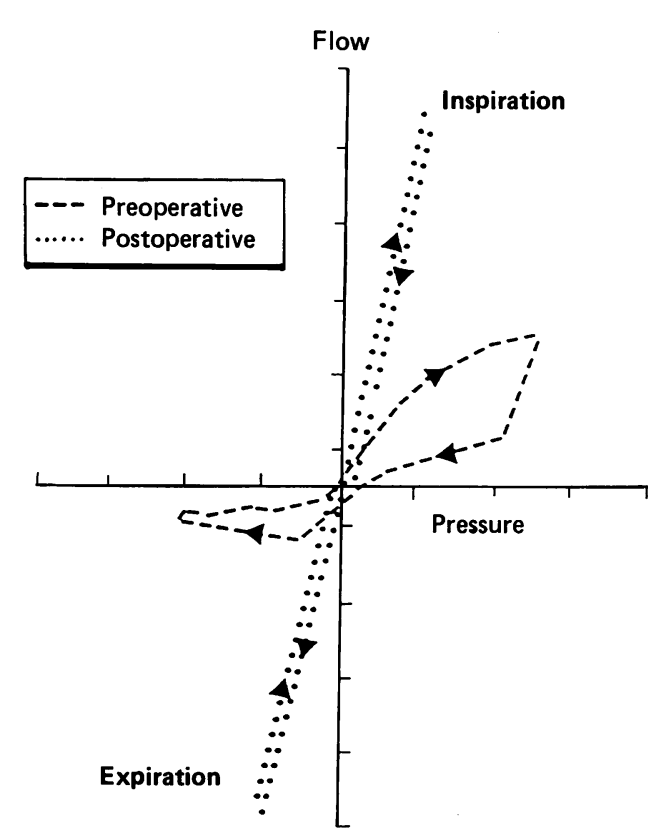

Figure 1 Pressure-flow curves from case 2 illustrating low flow rates despite high intrathoracic pressure preoperatively and a normal pressure flow curve postoperatively. Flow marker $=40 \mathrm{ml} / \mathrm{s}$, pressure marker $=4 \mathrm{cmH}_{2} \mathrm{O}$.

Expiration

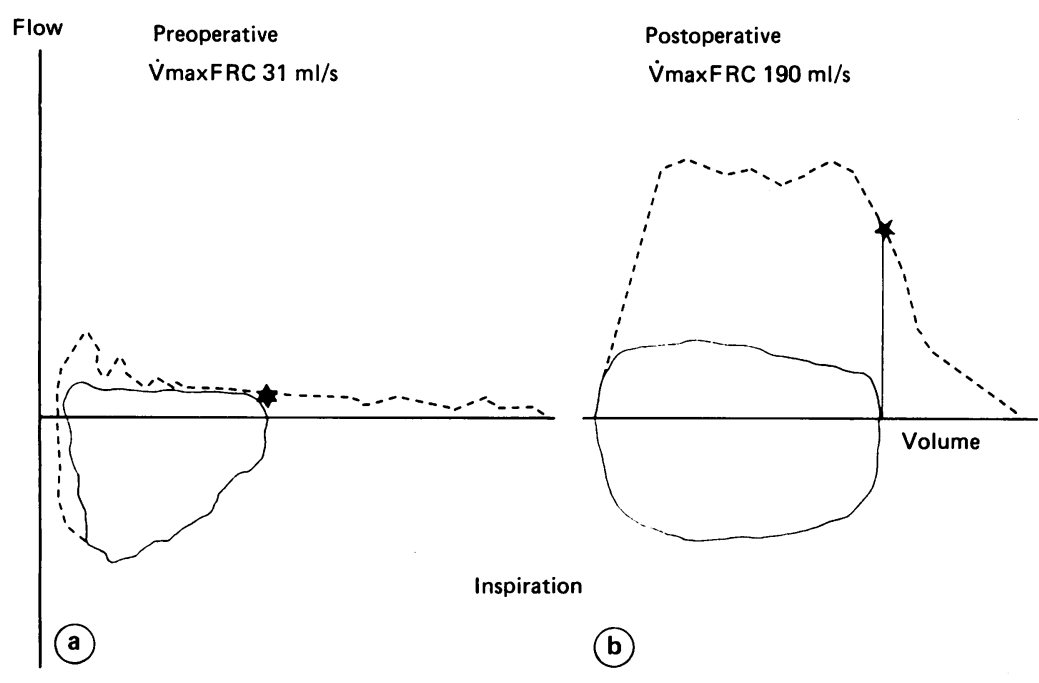

Figure 2 Flow-volume loops preoperatively and postoperatively in case 2.

increased inspiratory airways resistance, a normal thoracic gas volume, and normal VmaxFRC. Case 6 had normal airway function. These two infants had an incomplete vascular ring and the demonstration of normal intrathoracic airways function provided reassurance that the aortic arch anomaly was not related to the symptomatology.

\section{Discussion}

Most children with a vascular ring present with respiratory difficulty. Those with severe airway obstruction are more likely to have an early presentation. Nevertheless, vascular rings form only a small proportion of the infants with noisy breathing from birth, most of whom have laryn- gomalacia. A clinical clue in differentiation is expiratory as well as inspiratory stridor.

The cases presented illustrate that in the diagnosis of vascular ring there is no single diagnostic investigation. It was apparent at presentation that all the infants had upper airway obstruction. Clinical appraisal and investigation divided these into intrathoracic and extrathoracic obstruction. Respiratory function tests confirmed this distinction and documented the degree of airway dysfunction.

Airway function was assessed during both tidal breathing and forced expiration. Tidal flow-volume loops are technically easy to record in infancy and it has been suggested that they should be used in the evaluation of upper airway obstruction. ${ }^{7}$ This involves both pattern recognition and their objective numerical expiratory to inspiratory ratio. It is predictable that only infants with severe degrees of airway obstruction will demonstrate airflow abnormalities during tidal breathing and this was confirmed in our infants. Airways resistance, again measured during tidal breathing, is a much more sensitive test but infant whole body plethysmography is technically complex and time consuming. The patterns obtained from the airways resistance plots are more important than numerical data and clearly distinguish intrathoracic and extrathoracic obstruction, and the direction of the looping can describe the pathophysiology. ${ }^{8}$

A standardised technique for obtaining partial forced flow-volume loops in infancy has been developed, and the most commonly reported value is flow rate at functional residual capacity. ${ }^{59}$ Patterns of looping are less well described but a recent paper examined the importance of the shape of the curve when using a standardised compression pressure. ${ }^{10} \mathrm{~A}$ standardise compression pressure was not used in our infants but pressure adjusted to obtain the maximum flow rate for each infant. When airway obstruction is severe, flow limitation occurs even during tidal breathing (fig 2, case 2). A new parameter, introduced by Le Souef $e t a l,{ }^{10}$ of the ratio of forced maximum expiratory flow to tidal flow at midtidal volume (Vmid forced/ tidal) was also calculated in our patients and proved a good index of postoperative improvement. This parameter has the advantage of being a non-dimensional index of airflow obstruction unlike VmaxFRC, which must be considered either as a percentage predicted based on infant length or size corrected by dividing by the absolute lung volume at functional residual capacity. Both forced expiratory flow rates at functional residual capacity and Vmid forced/tidal give a clear indication of airways reserve. It is important to remember, however, that from numerical details alone, major intrathoracic airways obstruction cannot be distinguished from peripheral airway obstruction and lung function must be interpreted in the context of clinical data.

Long term follow up studies of patients with vascular ring have shown residual lung function abnormalities in over $50 \%,{ }^{3}$ even in those with complete resolution of symptoms. ${ }^{5}$ There was no association found between age at operation and outcome. The most severely compromised 
trachea is likely to present early but less severe compression may be present for years before it is detected. The relative importance of these factors on tracheal growth is unknown. The long term function abnormalities on testing have been attributed to either residual tracheomalacia or local tracheostenosis despite the relief of compression. Early postoperative airway assessment and subsequent follow up may provide evidence on the relative importance of these factors.

1 Gross RE. Surgical relief for tracheal obstruction from a 2 varcular ring. $N$ Engl f Med 1945;233:586-90. Vascular rings and slings: long-term follow-up of pulmonVascular rings and slings: long-term follow-up of
ary function. $\mathcal{F}$ Pediatr Surg 1984;19:683-93.

3 Bertrand J-M, Chartrand C, Lamarre A, Lapierre J-G.
Vascular ring: clinical and physiological assessment of pulmonary function following surgical correction. Pediatr Pulmonol 1986;2:378-83.

4 Stocks J, Levy N, Godfrey S. A new apparatus for the accurate measurement of airways resistance in infancy. F Appl Physiol 1977;43:155-9.

5 Silverman M, Prendiville A, Green S. Partial expiratory flowvolume curves in infancy: technical aspects. Bull Eur Physiopathol Respir 1986;22:257-262.

6 Shulman DL, Bar-Yishay E, Beardsmore CS, Beilin B, Godfrey S. Forced expiratory flow-volume curves in young 63:44-50.

7 Abramson AL, Goldstein MN, Stenzler A, Steele A. The use of the tidal breathing flow-volume loop in laryngotracheal disease of neonates and infants. Laryngoscope 1982;92: 922-6.

8 Stocks J, Thomson A, Wong C, Silverman M. Pressure flow curves in infancy. Pediatr Pulmonol 1985;1:30-40.

9 Taussig LM, Landau LI, Godfrey S, Arad I. Determinants of forced expiratory flows in newborn infants. $\mathcal{F}$ Appl Physiol forced expiratory flows in newborn infants. F Appl Physiol

10 Le Souef PN, Hughes DM, Landau LI. Shape of forced expiratory flow-volume curves in infants. Am Rev Resp Dis 1988;138:590-7. 